\title{
Pollutant levels in discarded fish species by Spanish trawlers operating in the Great Sole Bank and the Atlantic coast of the Iberian Peninsula
}

\author{
Luis T. Antelo ${ }^{1}$, Tatiana Ordóñez-del Pazo ${ }^{1}$, Carla Lopes ${ }^{1}$, Amaya Franco-Uría ${ }^{2, *}$, \\ Ricardo I. Pérez Martín ${ }^{1}$, Antonio A. Alonso ${ }^{1}$ \\ ${ }^{1}$ Marine Research Institute IIM-CSIC \\ Eduardo Cabello, 6 - 36208 Vigo, Spain. \\ ${ }^{2}$ Dept. of Chemical Engineering, School of Engineering, University of Santiago de Compostela \\ Campus Vida - 15705 Santiago de Compostela, Spain.
}




\begin{abstract}
Organic and inorganic pollutant levels were determined for the most discarded species from trawlers operating in Great Sole and Spanish coastal fishing grounds. Results for heavy metals indicated that $\mathrm{Cd}$ can reach values higher than legal limits for some species and tissues, while $\mathrm{Hg}$ and $\mathrm{Pb}$ concentrations are below stablished values. No significant variation was noticed with fishing grounds, but both season influence in the case of $\mathrm{Pb}$ and interspecies variation for $\mathrm{Hg}$ and $\mathrm{Cd}$ have been detected. Valorization recommendations could be therefore established according to the levels found in the different species.
\end{abstract}

Keywords Metals, persistent organic pollutants; discarded fish; tissues; valorization 
Discards are among the best examples of shortcomings that the Common Fisheries Policy (CFP) reform will amend, since this biomass is considered as impossible to justify to fishermen or the public (EC, 2013). The discards reduction and/or by-catch utilization must be undertaken to the possible extent in a manner that is consistent with the Code of Conduct for Responsible Fisheries (FAO, 1995). These objectives of FAO were presented in a specific technical report for discards reduction ("International guidelines for by-catch management and reduction of discards", in December 2010). The valorization of the inevitable unwanted by-catch is also the main motivation of the optimal and efficient discard management network that was and is being developed in FAROS and iSEAS projects, respectively. These projects were cofunded under the LIFE+ Environmental Program of the European Union (LIFE08 ENV/E/000119 - $\quad$ www.farosproject.eu $\quad$ and LIFE13ENV/ES/000131 www.lifeiseas.eu). The objective of these initiatives was to demonstrate a real sustainable valorization, and therefore, aspects like environmental impacts and consumer's safety issues associated with the valorization process must be addressed.

As a first step to attain sustainability, raw material quantification (percentage over the total discarded mass and quantity of each discarded specie in tones per year) and evaluation (status of stocks in their habitat as well as valorization potential) was carried out by the most discarded species in Great Sole Bank and Atlantic coast of the Iberian Peninsula (Ordóñez-del Pazo et al., 2014). Once the potential valorization strategy was established, the sustainable management of this biomass through its optimum recovery will depend on the quality of this new raw material, as well as of the products that may be obtained from it. Scientific studies, apart from fish product surveys on the markets of different countries and monitoring reports by the Public Administrations and the European Commission, reveal the presence of significant pollutant levels (particularly dioxins, PCBs, organochlorine pesticides and heavy 
metals) in the commercial species of different fisheries (Licata et al., 2005; Nadal et al., 2008; Miniero et al., 2014; Cano-Sancho et al., 2015). Therefore, it is logical to consider the more than possible presence of these pollutants in the discarded noncommercial species even though their levels are not usually determined (Antelo et al., 2012). Furthermore, significant differences on pollutants concentration depending on the considered tissue have been reported by several studies in literature (Kojadinovic et al., 2007; Afonso et al., 2007; Lozano et al., 2009; Webster et al., 2009). Organs like liver are well-known for preferentially accumulate higher pollutant concentrations (both inorganic and organic) (Bustamante et al., 2003; Coelho et al., 2010; Storelli et al., 2011a).

With this aim, the pollutant content has been analyzed in the most discarded species of these two fisheries areas, including heavy metals (mercury, lead and cadmium) and polychlorinated dibenzo-p-dioxins and dibenzofurans (PCDD/F) and dioxin-like polychlorinated biphenyls (dl-PCB), and pesticides. A statistical analysis of the data was performed on heavy metal levels. Besides, different target tissues were analysed for cartilaginous fish (liver, skin, and cartilage). This task is a key step in the correct definition of recovery strategies that may overcome the drawbacks arising from certain fish by-products (such as fishmeal, oil, etc.), which may concentrate pollutants to non-appropriate levels. Comparison with current legislation for commercial species was developed, taking into account the variability due to the analysed tissues.

Samples of discards were collected by scientific observers on board Spanish fishing trawlers operating in Great Sole and Spanish coastal waters (ICES Areas VIIb, VIIc, VIIg, VIIh, VIIj, VIIk, VIIIc and IXa) during 2011-2012 (Fig. 1). Samples for metals analysis were collected on a monthly temporal basis, while those for the determination of organic pollutants were collected seasonally (summer months in 2011 and winter months in 2012). A specific protocol for observers was created and 
implemented on board in order to properly define target species, required sample amounts, collection methodology, conservation and labelling requirements.

The sampled species and their target tissues were selected based on discarded amounts and their valorisation potential, this being analysed for the considered métiers (Ordóñez-del Pazo et al., 2014). Therefore, nine discarded species were selected for Great Sole fisheries and ten for coastal waters, taking into account that some of them were common for both fishing grounds (Table 1). The number of species was not constant depending on the sampling month, due to variations in presence of the different species among total capture. Around 5-15 individuals of each species were collected by month, depending on the type of analysis to carry out (heavy metals, organic pollutants or both). The clean and entire specimens where preserved on polyethylene bags placed on ice within hermetic boxes. On board collected data by species include date, haul number and location (throw net and pick up net coordinates). Samples characterization was subsequently completed in land. Once at laboratory, samples were frozen $\left(-25{ }^{\circ} \mathrm{C}\right)$ until the time of analysis (one week, approximately). Besides pollutant concentrations, species weight $(\mathrm{g})$, size $(\mathrm{cm})$ and gender were determined when possible, since some species were invertebrates and in other cases, immature individuals were collected.

Heavy metals determination was carried out in a laboratory that is homologated and accredited by the Spanish Entity of National Accreditation (ENAC) in accordance with regulation UNE-EN ISO/IEC 17025. Heavy metals ( $\mathrm{Hg}, \mathrm{Cd}$ and $\mathrm{Pb}$ ) were determined on $100 \mathrm{~g}$ of homogenized sample for the target tissue, which was obtained from at least two individuals of each specie. Acid digestion of the samples was carried out with nitric acid in a Berghoff microwave with several cycles of different duration and temperature until complete digestion was reached. The digestion products were carried to a volume of $100 \mathrm{~mL}$ with milliQ water. $\mathrm{Pb}$ and $\mathrm{Cd}$ were analyzed by electrothermal atomization, with a limit of quantification/detection (LOQ/LOD) $\geq 20$ 
$\mu \mathrm{g} \cdot \mathrm{kg}^{-1}$ and $\geq 8 \mu \mathrm{g} \cdot \mathrm{kg}^{-1}$ while $\mathrm{Hg}$ was analyzed by atomic fluorescence with a limit of detection $\geq 2.5 \mu \mathrm{g} \cdot \mathrm{kg}^{-1}$ (wet weight basis). Regarding the precision of both methodologies, the relative standard deviation of obtained measurements is $<1 \%$, as certified by the accredited laboratory.

An homogenized sample of $500 \mathrm{~g}$ for the target tissue was obtained from at least two individuals of each specie to perform organic pollutants analysis, according to requirements of EC Regulations (Regulation (EU) No. 589/2014 and Regulation (EU) No. 709/2015) in respect of methods and quality. For the determination of the 17 WHO congeners of polychlorinated dibenzo(p)dioxins and furans (PCDD/F) and the $12 \mathrm{WHO}$ congeners of dioxin-like polychlorinated biphenyls (dl-PCB), internal ${ }^{13} \mathrm{C}_{12}$ marked standards were added to the homogenized sample (isotope dilution method). Fat extraction was carried out by Accelerated Solvent Extraction (Dionex ASE 300) after mixture with diatomaceous earth. The fat extract was separated from the solvent by a rotatory evaporator, and after being purified by chromatography, analysis on PFCDD/F and dl-PCB were performed by high resolution gas chromatography/high resolution mass spectrometry (HRGC/HRMS) (LOQ between $0.1-0.8 \mathrm{pg}$ WHO-TEQ $\cdot \mathrm{g} \mathrm{fat}^{-1}$ ). Regarding organochlorine pesticides (OP) and pyrethroids, the sample material was extracted with acetone (acetone/water 2:1 v/v), accounting for the full natural water content of the sample. An organic extract was obtained through consecutive extractions with cyclohexane and ethyl acetate, being afterwards purified by chromatography. Finally, pollutants determination was performed by gas chromatography, using an electron capture detector (ECD) (LOQ between $0.001-0.01 \mathrm{mg} \cdot \mathrm{kg}^{-1}$ ).

Statistical analysis of obtained pollutant data in discarded species was carried out using R software (v3.1). Differences between fishing grounds, seasons and species were studied by the test two-way analysis of variance (ANOVA) at 95\% significance. For the specific case of the analysis of the relationship between season and metals (in 
particular, $\mathrm{Pb}$ ), a two-step, non-parametric method for multiple comparisons (KruskalWallis followed by Steel-Dwass-Critchlow-Fligner analysis) was applied to identify possible significant interactions. These methods use functions of the response ranks, called rank scores. The relationships between fish size (length and weight) and tissue metal concentrations were investigated by linear regression analysis. Pearson and/or Spearman correlation analysis were used to establish the association between variables. Significance levels were set at $\mathrm{p}<0.05$ ( $\mathrm{p}<0.001$ when specifically mentioned).

The results for $\mathrm{Hg}$, $\mathrm{Cd}$ and $\mathrm{Pb}$ by species are shown in Table 2. Obtained values were compared with legal limits established by Regulation (EC) No 1881/2006 and its amendments. These levels were established in most cases for fish meat/muscle mainly in commercial species and for that reason, only pollutants concentration in muscle or in the entire specimen were shown in Table 2. Moreover, based on the valorization potential, pollutant levels on shells (crustaceans), skin, cartilage (small-spotted catshark) and viscera (small-spotted catshark and black-mouthed dogfish) were also analyzed (Table 1), being the levels in these tissues discussed further on next pages. It must be pointed out that legal limits for some species of non-commercial origin were not available. In these cases, maximum levels for species in the same phyla were used for comparison purposes. In general, it can be observed that Hg and Cd presented higher levels than $\mathrm{Pb}$ (Carvalho et al., 2005), except for echinoderms, anemones and argentines. Different tendencies were also reported in literature regarding the levels of these three metals (Afonso et al., 2007; Kojadinovic et al., 2007; Storelli, 2008; Barone et al., 2013). Total Hg levels were below established limits for all sampled species in both fishing grounds, while $\mathrm{Pb}$ levels were higher than the legal limit only in one occasion in Great Sole Bank for sea anemone $\left(0.996 \mathrm{mg} \cdot \mathrm{kg}^{-1} \mathrm{ww}\right)$, although the concentration values for this specie were not directly comparable with legal limits (only for commercial species). However, Cd frequently exceeded regulation values, especially 
in coastal waters. Hg values presented more variability within each specie and also showed a significant variation among the different species considered (Naccari et al., 2015). For instance, Hg concentrations between horse mackerel and sea anemone were very different. The differences between values in both species are expected since they have dissimilar food habits and different behaviors. Horse mackerel presented the highest $\mathrm{Hg}$ concentrations in muscle in practically all the sampled months. The results found in this study and for this specie for $\mathrm{Hg}$ and $\mathrm{Pb}$ (average of 0.13 and $0.024 \mathrm{mg} \cdot \mathrm{kg}^{-1}$ ww, respectively) were comparable to those reported in Vieira et al. (2011), with mean values of $0.15-0.18$ and $0.016-0.014 \mathrm{mg} \cdot \mathrm{kg}^{-1}$ ww. However, average Cd concentrations were an order of magnitude higher in the present study $\left(0.018\right.$ in front of $0.007 \mathrm{mg} \cdot \mathrm{kg}^{-1}$ ww in the study of Vieira et al., (2011)). On the contrary, Storelli (2008) reported very similar average values of $\mathrm{Cd}$ and $\mathrm{Pb}$ for horse mackerel (0.02 and $0.03 \mathrm{mg} \cdot \mathrm{kg}^{-1} \mathrm{ww}$, respectively), but significantly higher values for $\mathrm{Hg}\left(0.68 \mathrm{mg} \cdot \mathrm{kg}^{-1} \mathrm{ww}\right)$. Naccari et al. (2015) also reported higher concentrations for $\mathrm{Hg}$ in horse mackerel and Atlantic mackerel $\left(0.220\right.$ and $\left.0.298 \mathrm{mg} \cdot \mathrm{kg}^{-1} \mathrm{ww}\right)$, while Cd was only detected for Atlantic mackerel at a higher concentration than this study $\left(0.120 \mathrm{mg} \cdot \mathrm{kg}^{-1} \mathrm{ww}\right)$ and lead was not detected in these species. Highest Hg concentrations in muscle of horse mackerel were also found by Vieira et al. (2011), which associated this fact to the predatory nature of horse mackerel. Triglidae (red and grey gurnard) and cartilaginous species (smallspotted catshark and black mouthed dogfish) also presented important concentrations, due to same reason (predatory species), whereas lowest $\mathrm{Hg}$ levels were found in sea anemone. Values of $\mathrm{Hg}$ in muscle of Scyliorhinus canicula $\left(0.108 \mathrm{mg} \cdot \mathrm{kg}^{-1} \mathrm{ww}\right)$ were comparable to those obtained for youngest specimens of this specie in Coelho et al. (2007) $\left(0.13 \mathrm{mg} \cdot \mathrm{kg}^{-1} \mathrm{ww}\right)$. These results are then another indication of the importance of biomagnification as distribution route of this metal through the trophic chain (Cai et al., 2007; Naccari et al., 2015). However, in the case of cadmium (Cd), the highest 
concentrations were found in sea anemone, crustaceans and small-spotted catshark. Boarfish (either in muscle and entire specimen) also presented high concentrations, as well as red gurnard, while the lowest cadmium concentrations were found in muscle tissues of black-mouthed dogfish and horse mackerel. The preferential accumulation of this metal in some species seems to be more related to physiological factors (like water and diet uptake, clearance rate) and environmental conditions (Franco-Uría et al., 2010; Vieira et al., 2011). In the case of sea anemone, the absence of both internal organs and mobility could favor the accumulation in this specie. Again, the highest concentrations in the case of lead $(\mathrm{Pb})$ were also found in sea anemone, followed by argentines, and with very similar results for the other species.

Levels of PCDD/Fs and dioxin-like PCBs as toxic equivalents (TEQ) in the analyzed species can be observed in Table 3. No statistical analysis was performed due to the low number of composite samples obtained. Of the screened OC pesticides, only DDT was detected in argentines $\left(0.005 \mathrm{mg} \cdot \mathrm{kg}^{-1}\right)$, horse mackerel $\left(0.004-0.005 \mathrm{mg} \cdot \mathrm{kg}^{-1}\right)$ and liver of small-spotted catshark $\left(0.037-0.051 \mathrm{mg} \cdot \mathrm{kg}^{-1}\right)$, but at low concentrations, well below legislation limits. The highest levels of PCDD/F and dl-PCB were observed in small-spotted catshark and boarfish, followed by triglidae, Atlantic mackerel and argentines. Levels of PCDD/F and dl-PBC in red gurnard were much lower than those reported in other studies (31.2 ng. $\mathrm{g}^{-1}$ lipid in Storelli et al., 2011a). Regarding mackerels, higher levels were also detected for either the two pollutants. dl-PCB were detected in horse mackerel at higher values (400 $\mathrm{ng} \cdot \mathrm{g}^{-1}$ lipid including other PCB congeners), but not detected in Mezzeta et al. (2011) in Atlantic mackerel, while values ranging from $0.004-0.0097 \mathrm{ng} \cdot \mathrm{g}^{-1}$ lipid of PCDD/F were reported in this specie (Karl et al., 2002). Regarding tissues, liver of small-spotted catshark did not present the highest values of organic pollutants, as happened with metals (metal values in different tissues will be discussed later on the text). Levels of pesticides in liver were lower than those 
obtained in other works (Mormede and Davis, 2003), as well PCDD/F content (Storelli et al., 2011b).

Associations between metals in the two fishing grounds were analyzed by correlation matrix, and can be summarized in Table 4. Cd and $\mathrm{Pb}$ are strongly correlated in both fishing grounds, thus indicating a common anthropogenic source for these pollutants and a similar bioaccumulation pattern. However, Hg was only partially and negatively correlated with $\mathrm{Cd}$ and $\mathrm{Pb}$ in Great Sole Bank, while in coastal waters no association was found. As mentioned before, $\mathrm{Hg}$ has a bioaccumulation behavior more related to the predatory habits of the species. Results of the two-way variance analysis ANOVA (Table 5) revealed that no statistically significant differences in heavy metal levels (Hg, Cd, Pb) were observed between fishing grounds. Selected species (those for which sufficient data is available - Table 5) showed statistical significant differences for $\mathrm{Hg}$ and $\mathrm{Cd}$, while for $\mathrm{Pb}$, no relevant differences were observed in the levels accumulated, as mentioned in the previous paragraph. Related with the influence of location on metal concentration, it is clear that anthropogenic pressure on marine areas will determine, among other factors, the concentration differences in marine species (Kress et al., 1999; Henry et al., 2004; Afonso et al., 2007; Antelo et al., 2012; Aoun et al., 2015; Naccari et al., 2015). However, it has to be considered the influence of the pollution level of a marine area in the trophic position of the specie. For example, high concentrations in benthic species are an indicator of bottom-contaminated sites, while the opposite behavior indicate clean bottom sediments (Henry et al., 2004; Naccari et al., 2015). More data would be needed to further study the influence of the fishing ground by each individual specie, considering those analyzed in this work.

Potential changes in heavy metal concentrations with the period/time of the year (seasonal study) were analyzed by two-way ANOVA test (Table S.1.), employing data of years 2011 and 2012. Winter season included January to March, spring comprises 
April to June, summer season included July to September and, finally, autumn corresponds to the period between October and December. No statistically significant seasonal differences were found for $\mathrm{Hg}, \mathrm{Cd}$ and $\mathrm{Pb}$ through the ANOVA analysis. However, obtained data from samples showed important differences in $\mathrm{Pb}$ levels along the year. Spring, summer and autumns months values were higher (range 0.0133-0.508 $\mathrm{mg} / \mathrm{kg}$ wet weight) than those obtained in winter months $(<0.02 \mathrm{mg} / \mathrm{kg}$ wet weight). A non-parametric analysis was applied to the aggregated data for $\mathrm{Pb}$ in each season (without species differentiation) to analyze once again seasonality on the levels of this heavy metals (Table S.2., Supplementary Information). First, a Kruskal-Wallis analysis was developed to test the general hypothesis that all population medians (for each season) are equal. Since the null hypothesis was rejected for this case $(p=0.00045)$, the next step was to compare the individual groups. This was done by using the SteelDwass-Critchlow-Fligner pairwise ranking method. In this case, the seasonality variations were verified since statistical significance is established between winter and the rest of considered seasons (Table S.2.). This finding could be explained by an increase in the lipid concentration related with feeding habits in summer months (Pethybridge et al., 2014), since Pb was reported to be at higher concentrations in highfat content species (Nadal et al., 2008; Vieira et al., 2011), and therefore, its bioaccumulation can be more related than other metals with the fat content of marine organisms. However, significant higher contents of $\mathrm{Pb}$ in species like horse mackerel or blue whiting were not observed in the present study.

Different tissues (liver, skin, cartilage, muscle and entire fish) were analyzed during sampling, although muscle and entire fish were the most frequently sampled, since the valorization potential of most species was the production of fishmeal or direct consumption (Table 1). Box plots of $\mathrm{Hg}, \mathrm{Cd}$ and $\mathrm{Pb}$ concentrations in the different sampled tissues are shown in Figure S1. Hg presented higher levels in skin and muscle 
than in liver of the two analyzed species, Galeus Melastomus and Scyliorhinus canicula. Hg was reported at higher levels in muscle than in liver (Zauke et al., 1999; Bustamante et al., 2003; Burger et al., 2007; Watanabe et al., 2012), even in demersal sharks (Pethybridge et al., 2010), including Scyliorhinus canicula (Coelho et al., 2010). However, higher concentrations are usually found in liver for high-size predators or benthic species (Bustamante et al., 2003; Afonso et al., 2007; Bebianno et al., 2007; Kojadinovic et al., 2007; Watanabe et al., 2012). Metal concentrations in the liver of the top predator small-spotted catshark and black-mouthed dogfish were those shown in Fig. S.1. In this case, Cd was accumulated at much higher levels in liver, while Hg and $\mathrm{Pb}$ were present at higher concentrations in skin. $\mathrm{Cd}$ is reported to be preferentially accumulated in liver for marine species belonging to different phyla, size or feeding habits (Henry et al., 2004; Kojadinovic et al., 2007; Bustamante et al., 2003; Burger et al., 2007; Ploetz et al., 2007; Barone et al., 2013) due to the metal-binding protein metallothionein, which has high affinity for $\mathrm{Cd}$. $\mathrm{Pb}$ would not captured by this protein so efficiently, which explain its lower levels in liver (Ploetz et al., 2007). However, Pb was found to be higher in livers of two species of sharks, being its content higher in the skin of one of the evaluated species (Lozano et al., 2009). Fig. S.2. shows the metal distribution in muscle and entire specimens of a small-size specie (boarfish). The results indicated that no significant differences were found in these fractions as expected, this consequently indicating that no important preferential accumulation in other tissues was produced in this specie, also caused by its low size. The pollutant level dependence in muscle with fish size (length and weight) was analyzed for only four species due to data availability (horse mackerel, sea anemone, blue whiting and triglidae). Only significant positive relationships $(\mathrm{P}<0.001)$ with length $(+0.921)$ and weight $(+0.918)$ were found for Hg in horse mackerel and moderate positive relationship $(\mathrm{P}<0.05)$ for blue whiting with length $(+0.797)$. in the case of horse mackerel. Several authors have found positive 
correlations for Hg with size, due to the bioaccumulation increase of this metal with age in predatory species (Bebianno et al., 2007; Burger et al., 2007; Coelho et al., 2010; Pethybridge et al., 2010).

When compared with legislation, Cd exceeded limit values in several occasions, while $\mathrm{Hg}$ and $\mathrm{Pb}$ remained below acceptable levels. Species most affected by $\mathrm{Cd}$ accumulation were sea anemone (all specimens but one), red gurnard, boar fish, and small-spotted catshark and black-mouthed dogfish, these latter cartilaginous species in liver. Other species like crustaceans or echinoderms presented punctual exceedance of legal limits. Globally, almost 30\% of samples presented Cd values higher than current legislation. Regarding pesticides, although maximum residue levels (MRLs) are not already established for fish or fish-derived products, the screening results were lower than general maximum pesticide limits of food products for human consumption. Species like sea anemone, red gurnard, boarfish, small-spotted catshark and horse mackerel, that were at first considered of interest for valorization purposes (based on the high amounts of discards generated by year in the selected fleets), could not be suitable for this aim due to the excessive levels of some metals. This is the case of $\mathrm{Cd}$ in sea anemone (especially those specimens coming from coastal waters), considering the medical uses of extracted compounds with anticancer cytotoxic and antimicrobial properties (Cao et al., 2005; Fedorov et al., 2010). In the case of red gurnard and boar fish, levels of Cd in entire fish suggests that further monitoring of metal levels should be performed, thinking in the production of fish meal, since legal limits are set to 1 $\mathrm{mg} \cdot \mathrm{kg}^{-1}$ (EC, 2002). Dietary intake of this type of feeds in cultured fish could be a main exposure pathway (Douben, 1989; Szebedinszky et al., 2001; Campenhout et al., 2007). Regarding cartilaginous species (small-spotted catshark and black-mouthed dogfish), the most suitable tissue for valorization purposes should be cartilage. High Cd levels found in muscle and in liver would impede either direct consumption (EC, 2006) or the 
extraction and concentration of valuable oil from these tissues, containing nutritional and valuable compounds (Blanco et al., 2007; Hareide et al., 2007). Besides, pollutants tend to be retained in the lipophilic phase, being oils in this case "natural" containers of these substances. This is the case for PCDD/F and dl-PCB, which were present in liver of small-spotted catshark, although at low values. In fact, several studies reported high levels of both inorganic and organic pollutants in oil produced from livers or entire organisms of marine species, either for fish feeds or direct human consumption (Eppe et al., 2005; Oterhals et al., 2007; Berntssen et al., 2010; Sprague et al., 2015). Skin also present important values of $\mathrm{Hg}$ and $\mathrm{Pb}$ in these species, and therefore, the production of gelatin or other compounds (Shyni et al., 2014; Limpisophon et al., 2015) must be subjected to precaution. Thus, although more than 4,000 tons of these species are discarded per year in these fisheries areas, the presence of heavy metals hampers their proper valorization. The recommendation would be to minimize the captures as much as possible. Horse mackerel presented the highest values for $\mathrm{Hg}$, but always below legal limits. However, the extraction of proteins and oils from this specie (Eymard et al., 2009; Gehring et al., 2009) must be undertaken together with a pollutant monitoring of both the raw material and the final obtained products. The remaining species shown in Table 1 presented low values of pollutant content, being this biomass optimal from the point of view of future valorization strategies for Spanish fleet. The results of this sampling are available in the Management Geoportal Network developed in FAROS project (www.farosproject.eu).

More monitoring of these fisheries, involving a wider temporal horizon and, what is more important, the inclusion of additional compounds, would be needed to confirm the main conclusions of this work. As an example, the presence of arsenic (even considering a small fraction of toxic inorganic As) in crustacean species could be a problem thinking in their future valorization. Regarding to this latter, another key 
factor would be to consider main species fractions in discarded marine organisms, where a wide scientific background exists in the literature, and the changes in metal speciation that the different valorization process might cause in the obtained products. On the other hand, the determination of total lipid content in discards is crucial to evaluate not only their nutritional value, but also to characterize bioaccumulation. Correlation empirical models should be established as a way to estimate concentration of several pollutants from this parameter. Finally, the distribution of pollutants within the intermediate products, effluents and final products of the different valorization processes must be also monitored. This would allow to know the safety of the process to consumers and to determine partition coefficients of the different contaminants within the process stages. These tasks are being currently developed in the framework of the iSEAS Project.

\section{Acknowledgement}

The authors acknowledge the financial support received from the LIFE+ Program of the European Union (FAROS Project - LIFE08 ENV/E/000119, LIFE iSEAS Project LIFE13 ENV/ES/000131). They also acknowledge the collaboration of the commercial fishing vessels, as well that given by the scientific observers, with the coordination from IEO during FAROS sampling. Amaya Franco-Uría belongs to the Galician Competitive Research Group GRC 2013-032, program co-funded by ERDF, and to CRETUS (AGRUP2015/02). Amaya Franco-Uría and Luis T. Antelo would also like to thank Secretaría de Estado de Investigación, Desarrollo e Innovación for the support provided by the “Ramón y Cajal” Subprogram. 


\section{References}

Afonso, C., Lourenço, H.M., Dias A., Nunes, M.L., Castro, M., 2007. Contaminant metals in black scabbard fish (Aphanopus carbo) caught off Madeira and the Azores. Food Chem. 101, 120-125.

Antelo, L.T., Lopes, C., Franco-Uría, A., Alonso, A.A., 2012. Fish discards management: Pollution levels and best available removal techniques. Mar. Pollut. Bull. 64, 1277-1290.

Aoun, M., Arnaudguilhem, C., El Samad, O., Khozam, R.B., Lobinski, R., 2015. Impact of a phosphate fertilizer plant on the contamination of marine biota by heavy elements. Environ. Sci. Pollut. R. 22, 14940-14949.

Barone, G., Giacominelli-Stuffler, R., Storelli, M.M., 2013. Comparative study on trace metal accumulation in the liver of two fish species (Torpedinidae): Concentrationsize relationship. Ecotox. Environ. Safe. 97, 73-77.

Bebianno, M.J., Santos, C., Canário, J., Gouveia, N., Sena-Carvalho, D., Vale, C., 2007. $\mathrm{Hg}$ and metallothionein-like proteins in the black scabbardfish Aphanopus carbo. Food Chem. Toxicol. 45(8), 1443-1452.

Berntssen, M.H.G., Olsvik, P.A., Torstensen, B.E., Julshamn, K., Midtun, T., Goksøyr, A., Johansen, J., Sigholt, T., Joerum N., Jakobsen, J.-V., Lundebye, A.-K., Lock, E.J., 2010. Reducing persistent organic pollutants while maintaining long chain omega-3 fatty acid in farmed Atlantic salmon using decontaminated fish oils for an entire production cycle. Chemosphere 81, 242-252.

Blanco, M., Sotelo, C.G., Chapela, M.J., Pérez-Martín, R.I., 2007. Towards sustainable and efficient use of fishery resources: present and future trends. Trends Food Sci. Tech. 18, 29-36.

Burger, J., Gochfeld, M., Shukla, T., Jeitner, C., Burke, S., Donio, M., Shukla, S., Snigaroff, R., Snigaroff, D., Stamm, T., Volz, C., 2007. Heavy metals in Pacific cod 
(Gadus macrocephalus) from the Aleutians: Location, age, size, and risk. J. Toxicol. Env. Heal. A 70, 1897-1911.

Bustamante, P., Bocher, P., Chérel, Y., Miramand, P., Caurant, F., 2003. Distribution of trace elements in the tissues of benthic and pelagic fish from the Kerguelen Islands. Sci. Total Environ. 313, 25-39.

Cai, Y., Rooker, J.R, Gill, G.A., Turner, J.P., 2007. Bioaccumulation of mercury in pelagic fishes from the northern Gulf of Mexico. Can. J. Fish. Aquat. Sci. 64, 458469.

Campenhout, K.V., Bervoets, L., Blust, R., 2007. Assimilation efficiencies of Cd and $\mathrm{Zn}$ in the common carp (Cyprinus carpio): effects of metal concentration, temperature and prey type. Environ. Pollut. 145, 905-914.

Cano-Sancho, G., Perelló, G., Maulvault, A.L., Marques, A., Nadal, M., Domingo, J.L., 2015. Oral bioaccessibility of arsenic, mercury and methylmercury in marine species commercialized in Catalonia (Spain) and health risks for the consumers. Food Chem. Toxicol. 86, 34-40.

Cao, S., Foster, C., Lazo, J.S., Kingston, D., 2005. Four diterpenoid inhibitors of Cdc25B phosphatase from a marine anemone. Bioorgan. Med. Chem. 13, 58305834.

Carvalho, M.L., Santiago, S., Nunes, M.L., 2005. Assessment of the essential element and heavy metal content of edible fish muscle. Anal. Bioanal. Chem. 382, 426- 432. Coelho, J.P., Santos, H., Reis, A.T., Falcão, J., Rodrigues, E.T., Pereira, M.E., Duarte, A.C., Pardal, M.A., 2010. Mercury bioaccumulation in the spotted dogfish (Scyliorhinus canicula) from the Atlantic Ocean. Mar. Pollut. Bull. 60, 1372-1375.

Douben, P.E.T., 1989. Metabolic rate and uptake and loss of cadmium from food by the fish Noemacheilus barbatulus L. (stone loach). Environ. Pollut. 59, 177-202. 
EC, 2002. Directive 2002/32/EC of the European Parliament and of the Council of 7 May 2002 on undesirable substances in animal feed.

EC, 2006. Commission Regulation (EC) No 1881/2006 of 19 December 2006 setting maximum levels for certain contaminants in foodstuffs.

EC, 2013. Regulation (EU) No 1380/2013 of the European Parliament and the Council of 11 December 2013 on the Common Fisheries Policy, amending Council Regulations (EC) No 1954/2003 and (EC) No 1224/2009 and repealing Council Regulations (EC) No 2371/2002 and (EC) No 639/2004 and Council Decision 2004/585/EC.

EC, 2015. Methods of sampling and analysis for the official control of food and feed complies with the requirements of the EC Regulations (Regulation (EU) No. 589/2014 and Regulation (EU) No. 709/2015 amending Regulation (EC) No. 152/2009).

Eppe, G., Carbonnelle, S., Hellebosch, L., De Meulenaer, B., Vila Ayala, J., De Greyt, W., Verhé, R., Goeyens, L., Focant, J., De Pauw, E., 2005. Removal of PCDD/Fs and DLPCBs from fish oil by activated carbon: compliance with European Legislation. Organohalogen Compd. 67, 1412-1416.

Eymard, S., Baron, C.P., Jacobsen, C., 2009. Oxidation of lipid and protein in horse mackerel (Trachurus trachurus) mince and washed minces during processing and storage. Food Chem. 114, 57-65.

FAO, 1995. Code of Conduct for Responsible Fisheries. Rome, FAO. 41p.

Fedorov, S., Dyshlovoy, S., Monastyrnaya, M., Shubina, L., Leychenko, E., Kozlovskaya, E., Jin J.-O., Kwak, J.-Y., Bode, A.M., Dong, Z., Stonik, V., 2010. The anticancer effects of actinoporin RTX-A from the sea anemone Heteractis crispa (Radianthus macrodactylus). Toxicon 55, 811-817. 
Franco-Uría, A., Otero-Muras, I., Balsa-Canto, E., Alonso, A.A., Roca, E., 2010. Generic parameterization for a pharmacokinetic model to predict Cd concentrations in several tissues of different fish species. Chemosphere 79, 377-386.

Gehring, C.K., Davenport, M.P., Jaczynski, J., 2009. Functional and nutritional quality of protein and lipid recovered from fish processing by-products and underutilized aquatic species using isoelectric solubilization/precipitation. Curr. Nutr. Food Sci. 5, 17-39.

Hareide, N.R., Carlson, J., Clarke, M., Clarke, S., Ellis, J., Fordham, S., Fowler, S., Pinho, M., Raymakers, C., Serena, F., Seret, B., Polti, S., 2007. European shark fisheries: a preliminary investigation into fisheries, conversion factors, trade products, markets and management measures. European Elasmobranch Association. Henry, F., Amara, R., Courcot, L., Lacouture, D., Bertho, M.-L., 2004. Heavy metals in four fish species from the French coast of the Eastern English Channel and Southern Bight of the North Sea. Environ. Int. 30, 675-683.

Karl, H., Ruoff, U., Blüthgen, A., 2002. Levels of dioxins in fish and fishery products on the German market. Chemosphere 49, 765-773.

Kojadinovic, J., Potier, M., Le Corre, M., Cosson, R.P., Bustamante, P., 2007. Bioaccumulation of trace elements in pelagic fish from the Western Indian Ocean. Environ. Pollut. 146, 548-566.

Kress, N., Herut, B., Shefer, E., Hornung, H., 1999. Trace element levels in fish from clean and polluted coastal marine sites in the Mediterranean Sea, Red Sea and North Sea. Helgoland Mar. Res. 53, 163-170.

Licata, P., Trombetta, D., Cristani, M., Naccari, C., Martino, D., Calò, M., Naccari, F., 2005. Heavy metals in liver and muscle of bluefin tuna (Thunnus thynnus) caught in the straits of Messina (Sicily, Italy). Environ. Monit. Assess. 107, 239-248. 
Limpisophon, K., Iguchi, H., Tanaka, M., Suzuki, T., Okazaki, E., Saito, T., Takahashi, K., Osako, K., 2015. Cryoprotective effect of gelatin hydrolysate from shark skin on denaturation of frozen surimi compared with that from bovine skin. Fisheries Sci. 81, 383-392.

Lozano, G., Brito, A., Hardisson, A., Gutiérrez A., González-Weller, D., Lozano, I.J., 2009. Content of Lead and Cadmium in Barred Hogfish, Bodianus scrofa, Island Grouper, Mycteroperca fusca, and Portuguese Dogfish, Centroscymnus coelolepis, from Canary Islands, Spain. B. Environ. Contam. Tox. 83(4), 591-594.

Maxwell, K. M., Gardner, J.P.A., Heath, P.L., 2009. The effect of diet on the energy budget of the Brown Sea Cucumber, Stichopus mollis (Hutton). Journal of the World Aquaculture Society 40, 157-170.

Miniero, R., Abate, V., Brambilla, G., Davoli, E., De Felip, E., De Filippis, S., Dellatte, E., De Luca, S., Fanelli, R., Fattore, E., Ferri, F., Fochi, I., Fulgenzi, A.R., Iacovella, N., Iamiceli, A.L., Lucchetti, D., Melotti, P., Moret, I., Piazza, R., Roncarati, A., Ubaldi, A., Zambon, S., di Domenico, A., 2014. Persistent toxic substances in Mediterranean aquatic species. Sci. Total Environ. 494-495, 18-27.

Naccari, C., Cicero, N., Ferrantelli, V., Giangrosso, G., Vella, A., Macaluso, A., Naccari, F., Dugo, G., 2015. Toxic metals in pelagic, benthic and demersal fish species from Mediterranean FAO Zone 37. B. Environ. Contam. Tox. 95, 567-573.

Nadal, M., Ferré-Huget, N., Martí-Cid, R., Schuhmacher, M., Domingo, J.L., 2008. Exposure to metals through the consumption of fish and seafood by population living near the Ebro River in Catalonia, Spain: health risks. Hum. Ecol. Risk Assess. 14, 780-795.

Mezzetta, S., Cirlini, M., Ceron, P., Tecleanu A., Caligiani, A., Palla, G., Sansebastiano, G.E., 2011. Concentration of DL-PCBs in fish from market of Parma city (north Italy): Estimated human intake. Chemosphere 2011, 1293-1300. 
Mormede, S., Davies, I.M., 2003. Horizontal and vertical distribution of organic contaminants in deep-sea fish species. Chemosphere, 50, 563-574

Ordóñez-Del Pazo, T., Antelo, L.T., Franco-Uría, A., Pérez-Martín, R.I., Sotelo, C.G., Alonso, A.A., 2014. Fish discards management in selected Spanish and Portuguese mètiers: Identification and potential valorisation. Trends Food Sci. Tech. 36, 29-43.

Oterhals, A., Solvanga, M., Nortvedt, R., Berntssen, M.H.G., 2007. Optimization of activated carbon-based decontamination of fish oil by response Surface methodology. Eur. J. Lipid Sci. Tech. 109, 691-705.

Pethybridge, H., Cossa, D., Butler, E.C.V., 2010. Mercury in 16 demersal sharks from southeast Australia: Biotic and abiotic sources of variation and consumer health implications. Mar. Environ. Res. 69, 18-26.

Pethybridge, H., Bodin, N., Arsenault-Pernet, E.-J., Bourdeix, J.-H., Brisset, B., Bigot, J.-L., Roos, D., Peter, M., 2014. Temporal and inter-specific variations in forage fish feeding conditions in the NW Mediterranean: lipid content and fatty acid compositional changes. Mar. Ecol.-Prog. Ser. 512, 39-54.

Ploetz, D.M., Fitts, B.E., Rice, T.M., 2007. Differential Accumulation of Heavy Metals in Muscle and Liver of a Marine Fish, (King Mackerel, Scomberomorus cavalla Cuvier) from the Northern Gulf of Mexico, USA. B. Environ. Contam. Tox. 78, $134-137$.

Quesada, A.J., Acuña, F.H., Cortes, J., 2014. Diet of the sea anemone Anthopleura nigrescens: composition and variation between daytime and nightthime high tides. Zoological Studies. 53:26.

Romero, M.C., Lovrich, G.A., Tapella, F., Thatje, S, 2004. Feeding ecology of the crab Munida subrugosa (Decapoda: Anomura: Galatheidae) in the Beagle Channel, Argentina. J. Mar. Ass. U.K. 84, 359-365. 
Shyni, K., Hema, G.S., Ninan, G., Mathew, S., Joshy, C.G., Lakshmanan P.T., 2014. Isolation and characterization of gelatin from the skins of skipjack tuna (Katsuwonus pelamis), dog shark (Scoliodon sorrakowah), and rohu (Labeo rohita). Food Hydrocolloid. 39, 68-76.

Sprague, M., Walton, J., Campbell, P.J., Strachan, F., Dick, J.R., Bell, J.G., 2015. Replacement of fish oil with a DHA-rich algal meal derived from Schizochytrium $s p$. on the fatty acid and persistent organic pollutant levels in diets and flesh of Atlantic salmon (Salmo salar, L.) post-smolts. Food Chem. 185, 413-421.

Storelli, M.M., 2008. Potential human health risks from metals (Hg, Cd, and $\mathrm{Pb}$ ) and polychlorinated biphenyls (PCBs) via seafood consumption: estimation of target hazard quotients (THQs) and toxic equivalents (TEQs). Food Chem. Toxicol. 46, 2782-2788.

Storelli, M.M., Barone, G., Perrone, V.G., Giacominelli-Stuffler, R., 2011a. Polychlorinated biphenyls (PCBs), dioxins and furans (PCDD/Fs): occurrence in fishery products and dietary intake. Food Chem. 127, 1648-1652.

Storelli, M.M., Barone, G., Storelli, A., Marcotrigiano, G.O., 2011b. Levels and congener profiles of PCBs and PCDD/Fs in blue shark (Prionace glauca) liver from the South-Eastern Mediterranean Sea (Italy). Chemosphere 82, 37-42.

Szebedinszky, C., Mcgeer, J.C., McDonald, D.G., Wood, C.M., 2001. Effects of chronic Cd exposure via the diet or water on internal organ-specific distribution and subsequent gill Cd uptake kinetics in juvenile rainbow trout (Oncorhynchus mykiss). Environ. Toxicol. Chem. 20, 597-607.

UNE-EN ISO/IEC 17025. Conformity assessment. General requirements for the competence of testing and calibration in laboratories.

Vieira, C., Morais, S., Ramos, S., Delerue-Matos, C., Oliveira M.B.P.P., 2011. Mercury, cadmium, lead and arsenic levels in three pelagic fish species from the 
Atlantic Ocean: Intra- and inter-specific variability and human health risks for consumption. Food Chem. Toxicol. 49, 923-932.

Watanabe, N., Tayama, M., Inouye, M., Yasutake, A., 2012. Distribution and chemical form of mercury in commercial fish tissues. J. Toxicol. Sci. 37, 853-861.

Webster, L., Walsham, P., Russell, M., Neat, F., Phillips, L., Dalgarno, E., Packer, G., Scurfield, J.A., Moffat, C.F., 2009. Halogenated persistent organic pollutants in Scottish deep water fish. J. Environ. Monitor. 11, 406-417.

Zauke, G.-P., Savinov, V.M., Ritterhoff, J., Savinova, T., 1999. Heavy metals in fish from the Barents Sea (summer 1994). Sci. Total Environ. 227, 161-173. 


\section{Figure captions}

Figure 1. Target ICES areas of the considered Spanish trawling fleet. 


\section{Table 1}

Characteristics and location of selected species, and tissues analyzed

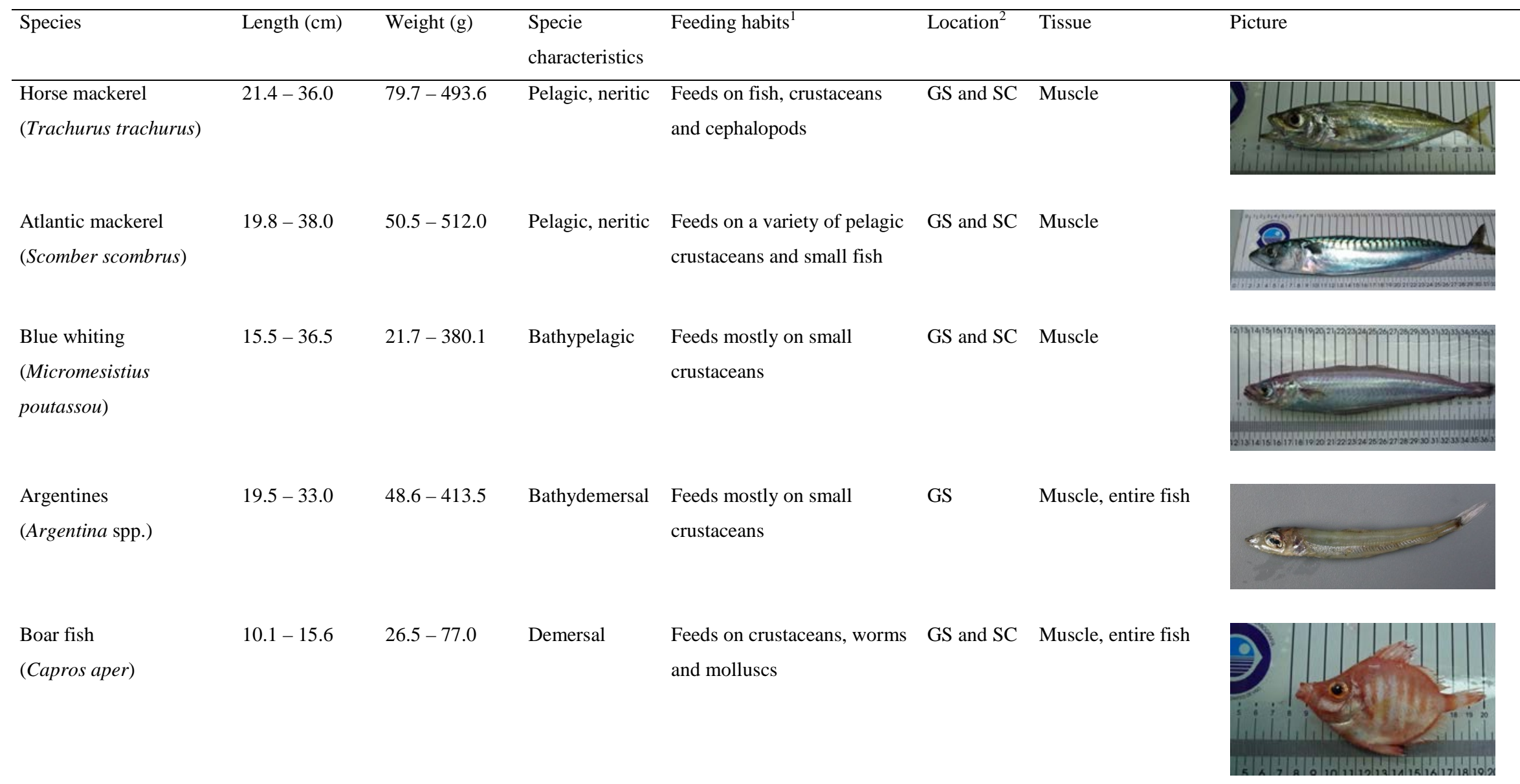




\begin{tabular}{|c|c|c|c|c|c|c|c|}
\hline Species & Length (cm) & Weight (g) & $\begin{array}{l}\text { Specie } \\
\text { characteristics }\end{array}$ & Feeding habits $^{1}$ & Location $^{2}$ & Tissue & Picture \\
\hline $\begin{array}{l}\text { Grey gurnard } \\
\text { (Eutrigla gurnardus) }\end{array}$ & $21.9-27.3$ & $103.2-165.3$ & Demersal & $\begin{array}{l}\text { Feeds on crustaceans and } \\
\text { fishes }\end{array}$ & SC & Muscle, entire fish & \\
\hline $\begin{array}{l}\text { Red gurnard } \\
\text { (Aspitrigla cuculus) }\end{array}$ & $18.8-26.4$ & $47.6-194.0$ & Demersal & $\begin{array}{l}\text { Feeds on crustaceans and } \\
\text { fishes }\end{array}$ & GS & Muscle, entire fish & \\
\hline $\begin{array}{l}\text { Black-mouthed dogfish } \\
\text { (Galeus melastomus) }\end{array}$ & $39.2-48.0$ & $187.0-383.3$ & Demersal & $\begin{array}{l}\text { Feeds mainly on bottom } \\
\text { invertebrates and small fishes } \\
\text { (bony and elasmobranchs) }\end{array}$ & SC & Entire fish, liver & \\
\hline $\begin{array}{l}\text { Small-spotted catshark } \\
\text { (Scyliorhinus canicula) }\end{array}$ & $29.9-63$ & $80.4-970.2$ & Demersal & $\begin{array}{l}\text { Feeds on a variety of benthic } \\
\text { invertebrates and small bony } \\
\text { fishes }\end{array}$ & GS and SC & $\begin{array}{l}\text { Muscle, cartilage, } \\
\text { skin, liver }\end{array}$ & \\
\hline $\begin{array}{l}\text { Sea anemone } \\
\text { (Actinauge richardi) }\end{array}$ & $3.5-6.4$ & $19.9-86.9$ & Benthic & $\begin{array}{l}\text { Feeds on the available prey, } \\
\text { usually benthic organisms }\end{array}$ & GS and SC & $\begin{array}{l}\text { Muscle, entire } \\
\text { specimen }\end{array}$ & \\
\hline
\end{tabular}




\begin{tabular}{|c|c|c|c|c|c|c|c|c|}
\hline Species & Length $(\mathrm{cm})$ & Weight (g) & $\begin{array}{l}\text { Specie } \\
\text { characteristics }\end{array}$ & Feeding habits $^{1}$ & Location $^{2}$ & Tissue & Picture & \\
\hline $\begin{array}{l}\text { Crustaceans } \\
\text { (Polybius henslowii, } \\
\text { Munida spp.) }\end{array}$ & $6.28-21.6$ & $7.92-15.6$ & Benthic & $\begin{array}{l}\text { Non-selective feeding } \\
\text { includes crustaceans, algae } \\
\text { and polychaetes (as a } \\
\text { predator) and particulate } \\
\text { organic matter (as a deposit } \\
\text { feeder) }\end{array}$ & SC & $\begin{array}{l}\text { Muscle, entire } \\
\text { specimen, shell }\end{array}$ & & 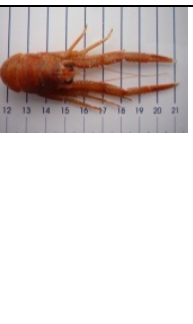 \\
\hline $\begin{array}{l}\text { Echinoderms } \\
\text { (Stichopus spp., } \\
\text { Holothuria spp.) }\end{array}$ & $17.5-26.0$ & $169.6-302.8$ & Benthic & $\begin{array}{l}\text { Detritivores that consume } \\
\text { organic matter }\end{array}$ & GS and SC & $\begin{array}{l}\text { Muscle, entire } \\
\text { specimen }\end{array}$ & $6>8$ & 1920212 \\
\hline
\end{tabular}

${ }^{1}$ From http://www.fishbase.org/; Quesada et al., 2014; Romero et al., 2004 and Maxwell et al., 2009

${ }^{2}$ GS: Great Sole Bank; SC: Spanish Coastal Waters 


\section{Table 2}

Heavy metal concentrations and legal maximum levels (ML) in discarded species (mg $\mathrm{kg}^{-1}$ wet weight) and number of composite samples (n)

\begin{tabular}{|c|c|c|c|c|c|c|}
\hline Specie & $\mathrm{Hg}$ & ML & $\mathrm{Cd}$ & ML & $\mathrm{Pb}$ & ML \\
\hline $\begin{array}{l}\text { Horse mackerel } \\
\text { (Trachurus trachurus) } \\
\mathrm{n}=10\end{array}$ & $\begin{array}{l}0.132 \pm 0.086 \\
(0.02-0.26)\end{array}$ & 0.5 & $\begin{array}{l}0.018 \pm 0.017 \\
(<0.008-0.06)\end{array}$ & 0.1 & $\begin{array}{l}0.024 \pm 0.016 \\
(0.01-0.07)\end{array}$ & 0.3 \\
\hline $\begin{array}{l}\text { Atlantic mackerel } \\
\text { (Scomber scombrus) } \\
\mathrm{n}=9\end{array}$ & $\begin{array}{l}0.046 \pm 0.041 \\
(0.01-0.15)\end{array}$ & 0.5 & $\begin{array}{l}0.021 \pm 0.010 \\
(0.01-0.04)\end{array}$ & 0.1 & $\begin{array}{l}0.024 \pm 0.010 \\
(<0.02-0.05)\end{array}$ & 0.3 \\
\hline $\begin{array}{l}\text { Blue whiting } \\
\text { (Micromesistius poutassou) } \\
\mathrm{n}=10\end{array}$ & $\begin{array}{l}0.056 \pm 0.044 \\
(0.008-0.13)\end{array}$ & 0.5 & $\begin{array}{l}0.032 \pm 0.037 \\
(<0.008-0.11)\end{array}$ & 0.05 & $\begin{array}{l}0.022 \pm 0.014 \\
(0.01-0.06)\end{array}$ & 0.3 \\
\hline $\begin{array}{l}\text { Argentines } \\
\text { (Argentina spp.) } \\
\mathrm{n}=3\end{array}$ & $\begin{array}{l}0.056 \pm 0.016 \\
(0.038-0.07)\end{array}$ & 0.5 & $\begin{array}{l}0.022 \pm 0.013 \\
(0.01-0.036)\end{array}$ & 0.05 & $\begin{array}{l}0.053 \pm 0.035 \\
(<0.02-0.09)\end{array}$ & 0.3 \\
\hline $\begin{array}{l}\text { Boar fish } \\
\text { (Capros aper) } \\
\mathrm{n}=11\end{array}$ & $\begin{array}{l}0.080 \pm 0.039 \\
(0.022-0.146)\end{array}$ & 0.5 & $\begin{array}{l}0.078 \pm 0.087 \\
(<0.008-0.259)\end{array}$ & 0.05 & $\begin{array}{l}0.032 \pm 0.017 \\
(<0.02-0.070)\end{array}$ & 0.3 \\
\hline $\begin{array}{l}\text { Grey gurnard } \\
\text { (Eutrigla gurnardus) } \\
\mathrm{n}=5\end{array}$ & $\begin{array}{l}0.098 \pm 0.110 \\
(0.006-0.28)\end{array}$ & 0.5 & $\begin{array}{l}0.040 \pm 0.057 \\
(<0.008-0.14)\end{array}$ & 0.05 & $\begin{array}{l}0.024 \pm 0.009 \\
(<0.02-0.04)\end{array}$ & 0.3 \\
\hline $\begin{array}{l}\text { Red gurnard } \\
\text { (Aspitrigla cuculus) } \\
\mathrm{n}=6\end{array}$ & $\begin{array}{l}0.152 \pm 0.162 \\
(0.015-0.41)\end{array}$ & 0.5 & $\begin{array}{l}0.009 \pm 0.005 \\
(<0.008-0.016)\end{array}$ & 0.05 & $\begin{array}{l}0.020 \pm 0.006 \\
(0.01-0.03)\end{array}$ & 0.3 \\
\hline $\begin{array}{l}\text { Black-mouthed dogfish } \\
\text { (Galeus melastomus) } \\
\mathrm{n}=4\end{array}$ & $\begin{array}{l}0.123 \pm 0.119 \\
(0.022-0.281)\end{array}$ & 1 & $\begin{array}{l}0.192 \pm 0.307 \\
(<0.008-0.649)\end{array}$ & 0.05 & $\begin{array}{l}0.045 \pm 0.050 \\
(<0.02-0.12)\end{array}$ & 0.3 \\
\hline $\begin{array}{l}\text { Small-spotted catshark } \\
\text { (Scyliorhinus canicula) } \\
\mathrm{n}=11\end{array}$ & $\begin{array}{l}0.108 \pm 0.118 \\
(0.018-0.390)\end{array}$ & 1 & $\begin{array}{l}0.194 \pm 0.346 \\
(<0.008-1.123)\end{array}$ & 0.05 & $\begin{array}{l}0.052 \pm 0.064 \\
(<0.02-0.24)\end{array}$ & 0.3 \\
\hline $\begin{array}{l}\text { Sea anemone } \\
\text { (Actinauge richardi) } \\
\mathrm{n}=9\end{array}$ & $\begin{array}{l}0.008 \pm 0.012 \\
(<0.002-0.04)\end{array}$ & 0.5 & $\begin{array}{l}0.662 \pm 0.782 \\
(0.041-2.65)\end{array}$ & 0.05 & $\begin{array}{l}0.155 \pm 0.317 \\
(<0.02-0.996)\end{array}$ & 0.3 \\
\hline
\end{tabular}




\begin{tabular}{lllllll}
\hline Specie & $\mathrm{Hg}$ & $\mathrm{ML}$ & $\mathrm{Cd}$ & $\mathrm{ML}$ & $\mathrm{Pb}$ & $\mathrm{ML}$ \\
\hline $\begin{array}{l}\text { Crustaceans } \\
\text { (Polybius henslowii, Munida spp., }\end{array}$ & $0.019 \pm 0.015$ & 0.5 & $0.207 \pm 0.343$ & 0.5 & $0.040 \pm 0.049$ & 0.5 \\
$\begin{array}{l}\text { Pagurus spp.) } \\
\mathrm{n}=7\end{array}$ & & & & & & \\
& & & & & \\
Echinoderms & & & & & & \\
(Stichopus spp.) & $0.010 \pm 0.002-0.15)$ & \\
$\mathrm{n}=4$ & $(0.004-0.03)$ & 0.5 & $0.037 \pm 0.024$ & 0.05 & $0.048 \pm 0.031$ & 0.3 \\
& & & $(0.01-0.068)$ & & $(<0.02-0.09)$ & \\
& & & & & & \\
\hline
\end{tabular}

Mean \pm standard error, range in parentheses 


\section{Table 3}

PCDD/F, dl-PCB's (pg/g fat) and pesticides (mg/kg) in discarded species, including information from Grand Sole and coastal waters fishing grounds, as well as different tissues analyzed

\begin{tabular}{|c|c|c|c|c|}
\hline Species & Location & Tissue & PCDD/F and dl-PCB & Pesticides \\
\hline $\begin{array}{l}\text { Boar fish } \\
\text { (Capros aper) }\end{array}$ & GS and SC & Entire fish & $0.668-0,685$ & $<\mathrm{LOQ}$ \\
\hline $\begin{array}{l}\text { Small-spotted catshark } \\
\text { (Scyliorhinus canicula) }\end{array}$ & GS and SC & Liver & $10,809-10,830$ & $<\mathrm{LOQ}$ \\
\hline $\begin{array}{l}\text { Red gurnard } \\
\text { (Aspitrigla cuculus) }\end{array}$ & GS & Muscle & $0.396-0.399$ & $<\mathrm{LOQ}$ \\
\hline $\begin{array}{l}\text { Argentines } \\
\text { (Argentina spp.) }\end{array}$ & GS & Entire fish & $0.438-0.440$ & 0.005 \\
\hline $\begin{array}{l}\text { Horse mackerel } \\
\text { (Trachurus trachurus) }\end{array}$ & GS and SC & Muscle & $0.181-0.211$ & 0.005 \\
\hline $\begin{array}{l}\text { Atlantic mackerel } \\
\text { (Scomber scombrus) }\end{array}$ & GS and SC & Entire fish & $0.373-0.394$ & $<\mathrm{LOQ}$ \\
\hline $\begin{array}{l}\text { Grey gurnard } \\
\text { (Eutrigla gurnardus) }\end{array}$ & SC & Entire fish & $0.532-0.546$ & $<\mathrm{LOQ}$ \\
\hline
\end{tabular}


Table 4

Correlation coefficient matrix between metal concentrations in Grand Sole bank and Coastal Spanish waters

\begin{tabular}{|c|c|c|c|}
\hline \multicolumn{4}{|c|}{ Great Sole Bank } \\
\hline & $\mathrm{Hg}$ & $\mathrm{Pb}$ & $\mathrm{Cd}$ \\
\hline $\mathrm{Hg}$ & 1 & & \\
\hline $\mathrm{Pb}$ & -0.715 & 1 & \\
\hline $\mathrm{Cd}$ & -0.699 & 0.945 & 1 \\
\hline \multicolumn{4}{|c|}{ Spanish Coastal Waters } \\
\hline & $\mathrm{Hg}$ & $\mathrm{Pb}$ & $\mathrm{Cd}$ \\
\hline $\mathrm{Hg}$ & 1 & & \\
\hline $\mathrm{Pb}$ & -0.289 & 1 & \\
\hline $\mathrm{Cd}$ & -0.186 & 0.973 & 1 \\
\hline
\end{tabular}


Table 5

Two-way ANOVA results for analysing the influence of specie and fishing ground in metal concentrations

\begin{tabular}{llllllll}
\hline & & $\mathrm{Hg}$ & $\mathrm{Cd}$ & \multicolumn{3}{c}{$\mathrm{Pb}$} \\
\hline & $\mathrm{df}$ & $\mathrm{F}$ & $\mathrm{p}$ & $\mathrm{F}$ & $\mathrm{p}$ & $\mathrm{F}$ & $\mathrm{p}$ \\
Fishing ground $^{\mathrm{a}}$ & 1 & 0.69 & 0.43 & 0.86 & 0.38 & 2.06 & 0.189 \\
Specie $^{\mathrm{b}}$ & 8 & 4.85 & 0.019 & 3.45 & 0.049 & 2.16 & 0.149 \\
& & & & & & & \\
Error & 8 & & & & & & \\
Total & 17 & & & & & & \\
\hline
\end{tabular}

$\mathrm{F}_{\text {critic }}$ for Fishing ground $=5.32(\alpha=0.05)$.

$F_{\text {critic }}$ for Specie $=3.44(\alpha=0.05)$.

${ }^{\mathrm{a}}$ Grand Sole Bank and Spanish Coastal waters

bSecies: sea anemone, boarfish, gurnards, horse mackerel, Atlantic mackerel, small-spotted catshark, blue whiting, equinoderms, crustaceans 
Table 6

Two-way ANOVA results for analysing the influence of specie and season in metal concentrations

\begin{tabular}{llllllll}
\hline & & $\mathrm{Hg}$ & $\mathrm{Cd}$ & \multicolumn{3}{l}{$\mathrm{Pb}$} \\
\hline & $\mathrm{df}$ & $\mathrm{F}$ & $\mathrm{p}$ & $\mathrm{F}$ & $\mathrm{p}$ & $\mathrm{F}$ & $\mathrm{p}$ \\
Season & 3 & 1.53 & 0.24 & 0.47 & 0.71 & 2.0 & 0.15 \\
Specie $^{\mathrm{a}}$ & 6 & 2.83 & 0.04 & 12.16 & 0.000017 & 1.44 & 0.25 \\
& & & & & & & \\
Error & 18 & & & & & & \\
Total & 27 & & & & & & \\
\hline
\end{tabular}

$\mathrm{F}_{\text {critic }}$ for Season $=3.16(\alpha=0.05)$.

$\mathrm{F}_{\text {critic }}$ for Specie $=2.66(\alpha=0.05)$.

${ }^{\text {a }}$ Species: sea anemone, boarfish, gurnards, horse mackerel, Atlantic mackerel, small-spotted catshark, blue whiting 
Table 7

Non-parametric multiple comparison test for the Pb levels obtained for the different seasons

Kruskal-Wallis test:

\begin{tabular}{lr}
\hline K (Observed value) & 17.947 \\
K (Critical value) & 7.815 \\
DF & 3 \\
p-value (bilateral) & 0.00045 \\
$\alpha$ & 0.05 \\
\hline
\end{tabular}

Steel-Dwass-Critchlow-Fligner pairwise comparison method ( $\mathrm{p}$-values; $\alpha=0.05$ ):

\begin{tabular}{lrrrr}
\hline & Winter & Spring & Summer & \multicolumn{2}{c}{ Autumn } \\
\hline Winter & $\mathbf{1}$ & $\mathbf{0 . 0 3 3}$ & $<\mathbf{0 . 0 0 0 1}$ & $\mathbf{0 . 0 1 0}$ \\
Spring & $\mathbf{0 . 0 3 3}$ & $\mathbf{1}$ & 0.795 & 0.829 \\
Summer & $<\mathbf{0 . 0 0 0 1}$ & 0.795 & $\mathbf{1}$ & 0.109 \\
Autumn & $\mathbf{0 . 0 1 0}$ & 0.829 & 0.109 & $\mathbf{1}$ \\
\hline
\end{tabular}

